\title{
THOUGHTS ON THE BRAZILIAN LIBERAL PROJECT'S FAILURE AT THE IMPERIAL ERA
}

\author{
Marcus Firmino Santiago \\ Centro Universitário do Distrito Federal - UDF
}

\begin{abstract}
Summary: INTRODUCTION. I. THE EUROPEAN REALITY OF THE EARLY NINETEENTH CENTURY, THE PORTUGUESE TRADITION AND THE COLONIAL HERITAGE. 1. Brazil on the Independence's Eve: a brief portrait. II. BUILDING THE COUNTRY: DIFFERENT STATE PROJECTS IN CONFLICT. 1 . Which were the groups that fought for the power and what they wanted? 2. The clash of ideas between the Constituent Assembly and the Emperor. 3. The granted Constitution: authoritarianism in the Brazilian constitutional genesis. III. THE LIBERAL THOUGHT SURVIVES: THE HOUSE OF DEPUTIES AS A SPACE OF RESISTANCE, THE COUP OF APRIL 07, 1831 AND A NEW BALANCE OF FORCES DURING THE REGENCY. IV. THE ADDITIONAL ACT: INTRODUCTORY NOTES AND ESSENTIAL ASPECTS OF A DECENTRALIZING EXPERIENCE. V. THE MYTH OF THE THRONE: THE INTERPRETATION LAW OF THE ADDITIONAL ACT, THE COUP OF LEGAL AGE AND THE STABILIZATION BASED ON THE CONSERVATIVE PROJECT. CONCLUSION.
\end{abstract}

\begin{abstract}
The word liberal was a constant presence in the speeches of the main leaders of the Brazilian State process of independence and formation. However, it's important to understand the different concepts of liberalism that were used by the political speech, frequently not linked to the reality. In fact, the new country stands firm to the Portuguese heritage, seeing in the authoritarian centralism of the monarchy the key to the State organization. Order, stability and unity are common values that guide political leaders of different orientations, placing themselves above any transformer project, especially those who could touch the social and economic structures centered on slavery.
\end{abstract}

Key words: Political liberalism. Authoritarianism. Brazilian State formation.

\section{INT RODUCTION}

The Brazilian institutional life analysis is always an enriching exercise, especially concerning to their specific characteristics that differentiate it from similar Europeans and, usually, make it very difficult to categorize in traditional legal frameworks. It's a pertinent observation when we discuss the national liberal tradition, theme particularly interesting in these times in which the word liberalism (but not necessarily with the meanings that it had before) is being so repeated.

Brazil emerged as an independent country in 1822, a time when Europe had been flooded by the liberal waves stirred by the French Revolution and the Napoleonic wars. The liberal political thought gave the keynote of modernity and was naturally embedded to the speech of the elites who have led the process of national independence, a group that became so delighted with the Porto Revolution and the Lisbon Courts. No wonder, therefore, that the European 
paradigm made itself present, influencing in the institutional design of the Brazilian State.

However, a more detained analysis of the forces' game present at the first half of the nineteenth century reveals that many of the ideas in vogue in Europe have landed here with different colors. The lexicon of the time and the disseminated and even random use of the term liberal helps to give an even more complex tone to the ideological conflicts present between independence and stabilization of the Second Reign, troubled period of national life marked by successive clashes between different political currents.

To understand the institutional legal design of the Brazilian State it is necessary to face some questions: Who are the Brazilian liberals of the first half of the nineteenth century and what is their State project? What is the trajectory of liberal political thinking in this first stage of institutional life? These are the issues that guide the present research, whose objective is to analyze the main ideological currents that dispute the primacy in the definition of a country project and understand the factors that provoke the collapse of the liberal project.

Therefore, it is necessary to outline the most striking attributes of the three ideological currents present at the time of independence and the dissolution of the Constituent Assembly (here called Monarchists with absolutist tendencies, Conservative Constitutionalists and Liberal Constitutionalists), to clarify the project of State of Conservatives and Liberals (remaining groups after the collapse of the nostalgics of the absolutism) and to understand the hegemonic model that is imposed in 1840' decade and that will characterize almost all the Second Reign. Thereby is that the proposed time-cutting limited the study between the events immediately related to the independence and the early years of King Pedro II government.

The research was based on bibliographic sources, highlighting the works of Raymundo Faoro, Octávio Tarquinio de Sousa and Aurelino Leal, authors representing different ideological lines, in a purposeful choice that aims to balance the various nuances and personal preferences that inevitably permeate the readings made about the Brazilian historical reality. Flanked by thinkers with different backgrounds, such as the jurist Paulo Bonavides or the economist Celso Furtado, this study seeks to weave a data network that allows sustainable analysis of Brazilian liberalism.

The research is justified not only by the constant need to revisit essential moments of Brazilian State formation, but especially by the influence that the events and debates of these early decades enforce on the next stages of national life. There is an undisputed logical thread between the imperial era and the following, a constant reliving of aspirations, ambitions and revenges that induce successive generations to hoist very similar flags. The present's understanding and the future's design depend on the proper vision of the past. In a moment in which the role of the Brazilian State is deeply rediscussed, the eyes cannot stray from the traditions, achievements and misconceptions that mark the national life. 


\section{THE EUROPEAN REALITY OF THE EARLY NINETEENTH CENTURY, THE PORTUGUESE TRADITION AND THE COLONIAL HERITAGE}

In the transition between the 1810' and 1820', European monarchies struggled to survive amid the uncontained whirlwind of claims by liberal matrix reforms, the legacy of the French Revolution and the conquests of Napoleon Bonaparte. The Vienna Congress, with its conservative concert, braked, but not avoided, the imminent collapse of the absolutist tradition.

The desire of the restored monarchs was to regain the throne splendor, supported by the structures of the old regimes, but there was no condition for it. The French values and their legislation, imposed by the strength of cannons and bayonets, put an end to the remains of servitude still in force, implemented the belief in civil equality before the law and abolished the privilege systems. ${ }^{1}$ New societies emerged from the wreckage of the Napoleonic Wars.

That was necessary to suppress social upheaval. There was a strong demand for order, stability, and the monarchical centralism was once again remembered as the solution. The time had come, however, to give in to survive, which initiated a conciliation process between elements of liberal constitutionalism with some typical traits of the old political regimes, in what is called Conservative Constitutionalism. Monarchy without despotism and freedom without anarchy: this was what the concert drawn at the Vienna Congress offered. ${ }^{2}$

As Fioravanti explains, in the early nineteenth century “(...) the fundamental value that encourages constitutionalism is that of the conservation of the social and political order of which everything derives, including rights, which can only find effective guardianship in the law of the sovereign State representative of that order."3 Emerged, then, Constitutions, sometimes promulgated by assemblies, sometimes granted based on the ancient monarchical principle, ${ }^{4}$ that reflected the agreement between the monarchy and the bourgeoisie, King and Parliament, in a system of reciprocal concessions that sought, on one hand, the fulfillment of liberal demands and, on the other, the conservation of the maximum of prerogatives for the Crown. ${ }^{5}$

1 MONDAINI, Marco. Guerras Napoleônicas. in MAGNOLI, Demétrio (org). História das Guerras. 3. ed. São Paulo: Contexto, 2006. p. 214.

2 MAGNOLI, Demétrio. Congresso de Viena (1814-1815). in MAGNOLI, Demétrio (org.) História da Paz. Os tratados que desenharam o planeta. São Paulo: Contexto, 2012. p. 77. On the topic, see also: LINCH, Christian Cyril. 'Monarquía sin despotismo y libertad sin anarquía'. Historia del concepto de liberalismo en Brasil (1750-1850). in SEBASTIÁN, Javier Fernández (org.). La Aurora de la Libertad. Los primeros liberalismos en el mundo ibero-americano. Madrid: Marcial Pons, 2012.

3 FIORAVANTI, Maurizio. Constitucionalismo. Experiencias históricas y tendências actuales. Madrid: Trotta, 2014. p. 19-20. Original text: “(..) el valor fundamental que anima al constitucionalismo es el de la conservación del orden social y politico del que todo deriva, incluidos los derechos, que solo pueden encontrar una tutela eficaz en la ley del Estado soberano representativo de ese orden."

4 To better understand the foundations of the constitutional grant, see the article of: LACCHÉ, Luigi. Las Cartas Otorgadas. La teoria de l'octroi y las experiencias constitucionales en la Europa post-revolucionaria. In Fundamentos. Cuadernos Monográficos de Teoría del Estado, Derecho Público e Historia Constitucional. Oviedo: Junta General del Principado de Asturias, n. 6. 2010.

5 FIORAVANTI, Maurizio. Constitucionalismo... Op. cit., p. 98. 
Absolutism, however, was not dead. Portugal was one of the States that resisted, as long as it could, despising the renovating winds, remaining firmly in his centralist and authoritarian tradition. Faithful to the legacy of the Marquis of Pombal, King João VI remained clinging to the notion that social and liberal transformation would be made from the State, not from the society. The renewal claimed by so many (along with the return of the King to the motherland) found the attachment to a tradition of change from above as an answer, which allowed the monarch to believe that only by his action something would be transformed at the State structure. ${ }^{6}$

The Portuguese Crown believed to be able to contain the revolutionary turbulences that already surpassed Europe and reverberated in the neighbors of the American continent, betting on a reformism that demanded of the monarchy "(...) anticipate any pressures that would arise in society, satisfying them to the extent of their convenience. It was this logic of prevention of the revolution and sowing of the gradual change's theories (...)".7

Portugal's insistence on keeping itself apart of the European conservative concert (which also showed extreme fragility) ended up charging its price. Triggered in August 1820, the liberal Porto Revolution quickly succeeded in imposing the liberal ideals, alive at Spain of the Constitution of Cadiz (promulgated in 1812) and engine of revolts in countries as diverse as France, Belgium, Poland and Greece. ${ }^{8}$ The concepts and experiences of the French and Spanish movements finally landed in Portugal: "An example of this is the concept of sovereignty, which no longer passed by the king, but by the citizens; (...) The king would be the first of the citizens, the executor of the common interest, but no more the only sovereign." 9

It is curious to note that the attachment to the statism and the strength of the Marquis of Pombal's inheritance were so decisive that the liberal movement, lastly imposed by the force of the Porto Revolution, also submitted itself to this model. The transaction of the nobility with the mercantile bourgeoisie has incorporate to the Portuguese State a liberalism “(...) official and directed from the top, as appendix of the State". ${ }^{10}$

6 FAORO, Raymundo. Existe um Pensamento Político Brasileiro? in COMPARATO, Fábio Konder (org.). A República Inacabada. São Paulo: Globo, 2007. p. 69.

7 LINCH, Christian Edward Cyril. Conservadorismo Caleidoscópico: Edmund Burke e o pensamento político do Brasil oitocentista. Revista Lua Nova. São Paulo, n. 100, 2017. p. 326. Original text: “(...) antecipar-se às eventuais pressões que surgiriam na sociedade, satisfazendo-as na medida de suas conveniências. Foi essa lógica de prevenção da revolução e semeadura das teses de mudança gradual (...)"

8 Some among several countries and regions in which there were revolts with liberal ideological guidance during the 1820 decade, opposing to restored regimes in the form of the Vienna concert. LESSA, Antônio Carlos. História das Relações Internacionais. A Pax Britannica e o mundo do século $X I X$. Vol. I. 4. ed. Petrópolis: Vozes, 2011. p. 53-57; 66-75.

9 GOMES, Jônatas Roque Mendes. A revolução liberal do Porto e as concepções de pacto social no parlamento brasileiro (1826-1831). Passagens. Revista Internacional de História e Cultura Jurídica. Vol. 10, n. 1. Rio de Janeiro, jan./abr. 2018. p. 27-28. Original text: "Um exemplo disto é o conceito de soberania, que não mais passava pelo rei, mas sim pelos cidadãos; (...) O rei seria o primeiro dos cidadãos, o executor do interesse comum, mas não mais o único soberano."

10 FAORO, Raymundo. Existe um Pensamento Político Brasileiro? Op. cit., p. 73-74. Original text: “(...) oficial e dirigido do alto, como apêndice do Estado." 


\section{Brazil on the Independence's Eve: a brief portrait}

The Portuguese State tradition was incorporated into Brazilian political thinking and practices by different ways. The most obvious and even self-evident was the United Kingdom status, acquired by Brazil with the change of the royal family, fleeing from the invasion of the Napoleonic troops. The profound changes experienced during the colonial period, by hosting the Court, followed the script already incorporated by Portuguese statism: strong decision-making centrality, uncontested authoritarianism, heavy administrative machine, rigid social hierarchy based on nobility's titles and in employments granted in the State bureaucracy.

Despite the strong and rapid transformations promoted thanks to the new political status acquired by Brazil, on the eve of 1820 the Brazilian population was still largely formed by illiterate people, residents in rural areas and heavily dispersed by a vast territory. Higher education was a novelty, just like the press. Information circulated in a very precarious way in an atomized society, but that was already beginning to build timid identity ties. ${ }^{11}$

Although the almost exclusive economic activity was intensive farming, there were no great fortunes in the field. In the words of Faoro, "(...) there were extensive properties, proportionately of scarce remuneration (...) The colonial landlordism were largely vacant and could not, under these conditions, guarantee an income not even sufficient and stable." 12 The wealth was concentrated in a small group of traders, intermediaries who financed the crops and maintained close ties with the public administration. However, even economically fragile, the agricultural lords composed the class that would come to seize the power with Independence and, as still will be seen, even more so after $1831 .{ }^{13}$

Regional diversity is also a factor that deserves prominence and exerted decisive influence on the Brazilian State's formation process and in many subsequent disputes.

None of the regions of the country had sufficient ancestry, whether political, or economic, over the others to impose the unit. In fact, regional interests were a much more tangible reality than the national unity, which only really began to be sketched when the Portuguese Government transferred to Rio de Janeiro. ${ }^{14}$

This dissent and dispute's climate remained alive in the 1810's and it clearly appeared when the Porto Revolution broke out. At that time, even before the Crown took a stand on the claims of the rebellious, Pará, Pernambuco, Maranhão and Bahia proclaimed their allegiance to the Lisbon Courts, an attitude which, shortly thereafter, would create difficulties to reconcile different and antagonistic interests present in Independence. And it would also help to justify the centralism

${ }^{11}$ LINCH, Christian Edward Cyril. Conservadorismo Caleidoscópico. Op. cit., p. 325.

12 FAORO, Raymundo. Existe um Pensamento Politico Brasileiro? Op. cit., p. 83-84. Original text: “(...) o que havia eram extensas propriedades, proporcionalmente de escassa remuneração (...) Os latifúndios coloniais apresentavam-se, em larga proporção, baldios e não podiam, nestas condições, assegurar um rendimento sequer suficiente e estável."

13 FURTADO, Celso. Formação Econômica do Brasil. 34. ed. São Paulo: Companhia das Letras, 2007. p. 144.

14 FURTADO, Celso. Formação Econômica do Brasil. Op. cit., p. 143-144. 
assumed by the King Pedro I, supported by the discourse of the monarchical authority as the only remedy for the risk of fragmentation, avoiding to repeat the experience of Spanish America. Brazil already started its history in the opposite of the European trajectory and the American practices.

In the early 1820, the Vienna-born European conservative concert was under pressure from all sides, cornered by struggles against the monarchical absolutism's remnants, the affirmation of popular sovereignty, the rule of law and the Constitutions' supremacy. Portugal was swallowed by the liberal wave, which flocked enthusiastically several Brazilian political leaders. Multiple indications allowed to foresee the success of liberal thinking in the Independence process that was approaching in firm steps.

However, with Independence it would also come “(...) the abandonment of the liberal platform, in favor of the construction of the Empire. This line shall adopt the name, without conserving the thing, not by cunning, but by limiting the principle within the transmigrated State."15 How to explain Faoro's words, synthesis of the trajectory of Brazil liberalism, emptied of meaning and seized by the structure of power established? What allowed the triumph of the conservative and centralist project in a context of free expansion of liberal values?

\section{BUILDING THE COUNTRY: DIFFERENT STATE PROJECTS IN CONFLICT}

An official speech was quickly signed, supported by the need to face the prevailing dissensions between the Provinces, in order to justify the concession of all authority to the monarch. As Octaciano Nogueira notes:

When the Constitution was granted, the example of Spanish America, fractured by local particularisms created from the colonial administration, had produced its fruits. There was in Brazil, especially after the liberal Porto Revolution, in 1820, the founded fear that this example might repeat. ${ }^{16}$

This fear was certainly not unfounded, nor was it present only in the immediate years to Independence. In fact, there were several movements contrary to central power, many of which with separatist nature. ${ }^{17}$ And it's necessary to highlight the lack of internal unity. Octaciano Nogueira recalls that in the early nineteenth century, in vast regions of Brazil the dominant language was not the Portuguese, but the Tupiguarani, idiom of one of the multiple traditional

15 FAORO, Raymundo. Existe um Pensamento Politico Brasileiro? Op. cit., p. 96. Original text: “(..) o abandono da plataforma liberal, em favor da construção do Império. Essa linha adotará o nome, sem conservar a coisa, não por astúcia, mas pela limitação do princípio dentro do estado transmigrado."

16 NOGUEIRA, Octaciano. Constituições Brasileiras: 1824. Vol. I. Brasília: Senado Federal, 2001. p. 28. Original text: "Quando a Constituição foi outorgada, o exemplo da América Espanhola, fracionada em razão dos particularismos locais criados a partir da administração colonial, tinha produzido seus frutos. Havia no Brasil, sobretudo depois da Revolução Liberal do Porto, em 1820, o procedente temor de que esse exemplo se repetisse."

17 CASTRO, Araújo. A Constituição de 1937. edição fac-similar. Brasília: Senado Federal, 2003. p. 19. 
indigenous nations. ${ }^{18}$ Anyway, different authors (among which Euclides da Cunha and Oliveira Viana) attribute the Brazilian territorial unit to the monarchy, seeing it as an instrument of social and cultural integration essential to the construction of links between the human groups inhabiting the territory.

Not everyone, however, shared the certainty of monarchical centralism as the only remedy. As Nelson Saldanha explains, there were important leaderships that saw in a Republican regime a possible way to achieve the same result. ${ }^{19}$ If not the Republic, at least a constitutional monarchy founded on liberal principles, such as popular sovereignty, supremacy of the law, separation of powers and enhancement of the representative system.

\section{Which were the groups that fought for the power and what they wanted?}

Three great ideological strands coexisted in the moments surrounding the proclamation of Independence: on one end, disappointed monarchists by the breaking of absolutism in Portugal and willing to maintain this model in Brazil; in the other, inebriated by the European liberals, defenders of the Republic and administrative decentralization; in an intermediate position, a group approaching the Viennese conservative constitutionalism, with its blend of monarchical centralism tempered by liberal values.

At first, it is noted that the Liberal nickname is used by both the second group - also called the Exalted - as for the third, the Moderate, who years later would be known as Conservatives. This data immediately casts doubts about the meaning that each one attaches to the term. More complex is the semantic analysis when the debate on democracy composes this equation.

The despotism of the mobs, expression used in the years 1860 by Teofilo Otoni, ${ }^{20}$ is feared by all in 1822, the democrat label was something widely rejected. ${ }^{21}$ Even those seen as more radicals treated very sparingly subjects such

18 NOGUEIRA, Octaciano. Constituições Brasileiras. Op. cit., p. 28. In a diverse sense pointed out Nelson Saldanha, for whom: "Sociologically, it can already be considered as existing, at that time, a certain number of Brazilian representatively social traits, which characterize the mode of this transition. A serious transition, this of the colonial stage, larvae, to the stage of existence as a free nation (at least in the formal and political, or legal sense). The ethnic injections had given us the most varied African components, to join the indigenous, and to the whites: hence to say José Honório Rodrigues that Brazil was successively Tupinizado, Africanized, Easternized and Westernized, and that from so many antithesis the synthesis should be a singular product." (Original text: "Sociologicamente, já se pode considerar como existente, naquele tempo, um certo número de traços sociais representativamente brasileiros, que caracterizam o modo desta transição. Uma transição gravissima, esta do estágio colonial, larvar, ao estágio de existência como nação livre (ao menos no sentido formal e político, ou jurídico). As injeções étnicas nos tinham dado componentes africanos os mais variados, para juntar-se aos indigenas, e aos brancos: dai dizer José Honório Rodrigues que o Brasil foi sucessivamente tupinizado, africanizado, orientalizado e ocidentalizado, e que de tantas antiteses a sintese a sair devia ser um produto singular.")

SALDANHA, Nelson Nogueira. História das Ideias Políticas no Brasil. Brasília: Senado Federal, 2001. p. 92.

19 SALDANHA, Nelson Nogueira. História das Ideias Politicas no Brasil. Op. cit., p. 108.

20 COMPARATO, Fábio Konder. Prefácio. in COMPARATO, Fábio Konder (org.). A República Inacabada. São Paulo: Globo, 2007. p. 16.

${ }^{21}$ Octávio Tarquínio de Souza describes a curious discussion during the Constituent Assembly, which well expresses this context: “(...) Congressman Henrique de Resende (...) certainly chose the 
as popular sovereignty and preferred to put aside discussions on social equality or the abolition of slavery, going against the basic postulates of European liberalism. After all, it should be remembered, this ideology was born as the antithesis of tyranny and deposited in the sovereign popular will the hope of sustaining State power on rational and controllable bases. ${ }^{22}$

The typical European liberal thinking, based in the defense of individual freedom, general submission - including the rulers - to the law, popular sovereignty and the strength of the representative systems was far from being shared by the hegemonic groups. In truth, as Jorge Caldeira informs, "at the time, those who thought so were exception - and their ideas, more innovation of revolutionaries than principles settled." 23

Then, what did these groups advocate?

The Absolutists were concerned with the centralization and dominance of State instruments to control trade, with the guarantee of debts and sales of slaves. ${ }^{24}$ Led by the great traders, almost always people born in Portugal, and integrated by the circle closest to the Crown, they defended the typical centralizing and authoritarian tradition of the Bragança dynasty. ${ }^{25}$ Despite the strong identification with King Pedro I, the Absolutists did not tell, at first, with their enthusiasm, having the new Emperor chosen to pass between the different chains, prefering to support his authority in his charism than that in specific social segments.

moment to wash himself from the image of republican and democrat, who had endangered his chair in the assembly. (...) He was careful to declare himself openly an enemy of democracy, not by passing the democratic principles of 'old coins found under old ruins'. It is curious to point out how, at the time of the Constituent, a dangerous and subversive meaning was given to that word. Being a democrat was what is today to be socialist or communist." (Original text: "(...) o Deputado Henrique de Resende (...) escolheu sem dúvida o momento para lavar-se da pecha de republicano e de democrata, que fizera perigar a sua cadeira na Assembleia. (...) teve o cuidado de declarar-se abertamente inimigo da democracia, não passando os principios democráticos de 'antigas moedas achadas debaixo de velhas ruinas'. É curioso assinalar como, ao tempo da Constituinte, se dava a essa palavra uma significação perigosa e subversiva. Ser democrata era o que hoje é ser socialista ou comunista.") SOUSA, Octávio Tarquínio de. Três Golpes de Estado. História dos Fundadores do Império do Brasil. São Paulo: Editora USP, 1988. p. 30.

22 BARRADAS, Abril Uscanga. Problemas de la democracia liberal: un breve análisis. Revista Brasileira de Direito. Passo Fundo, vol. 14, n. 1, Jan./Abr. 2018. p. 22.

In the Brazilian scenery of the time, as Fábio Konder Comparato synthesizes, “(...) the nefarious character of the democratic regime, capable of subvert the natural order of society, was a widely accepted idea at the time." (Original text: “(..) o caráter nefasto do regime democrático, porque subversor da ordem natural da sociedade, era uma ideia amplamente aceita na época.") COMPARATO, Fábio Konder. Prefácio. Op. cit., p. 15.

23 CALDEIRA, Jorge. Introdução. in CALDEIRA, Jorge (org). Diogo Antonio Feijó. Coleção Formadores do Brasil. São Paulo: Editora 34, 1999. p. 14. Original text: "Na época, aqueles que pensavam assim eram exceção - e suas ideias, mais inovação de revolucionários que princípios assentados."

24 FAORO, Raymundo. Os Donos do Poder. Formação do patronato politico brasileiro. 3. ed. São Paulo: Globo, 2001. p. 337.

25 BONAVIDES, Paulo; ANDRADE, Paes de. História Constitucional do Brasil. 3. ed. São Paulo: Paz e Terra, 1991. p. 97. 
The intense presence of liberal thought served as a brake on the pure and simple continuity of the Portuguese monarchist tradition. "The liberal bath, irradiated from the Portuguese and Brazilian events of the last two years, did not allow the passive adoption of the absolutist system." 26 In a consistent manner with the dominant European reality, an expressive portion of the Brazilian elite see no space to incorporate the Portuguese inheritance, and reputed inadmissible, in the nineteenth century, to generate a country tied to medieval values.

Rural landowners, intellectuals, military, small traders and urban elites, especially composed of liberal professionals and clergymen, were the main segments that communed with the liberal creed, divided, however, between two currents that soon became antagonists.

The balance between freedom and order was the horizon that moved the Moderate group, for whom the monarchy was the only alternative that could contain what they saw as anarchy. This term, by the way, was largely used to designate any action that could question the strong and centralized power, whether by the defense of the federation, the republic or - supreme boldness to which few dared - the change in social structure and abolition of slavery. ${ }^{27}$

The moderate ideals were very close to the conservative consensus framed in the Vienna Congress. The monarchy without despotism combined with the freedom without anarchy formed the key element to orient its State project, in which it was accepted, without great embarrassment, the precedence of the monarch on the Constitution and on the popular will, placing in the Crown the key to the organization and functioning of the State power. ${ }^{28}$ In resume, a liberalism capable of living with the monarchical principle, for whom the popular sovereignty represented a risk and which admitted that the Constitution served as an instrument to homologate an authority that preceded it. And even when disconnected from its contents, the label continued to be used for a long time.

The Exalted were also liberals whose State project assumed by premise the principle of popular sovereignty to combat not only absolutism, but the monarchy itself. Transiting between the North-American experience and the Rousseau's strands of the French Revolution, they advocated the republic and the federation, in a decentralized model where the government was effectively subjected to the rule of law. ${ }^{29}$

The position of the Exalted was very clearly approaching the European thought matrix, but it did not entirely reproduce it. This is explained in a great margin by the predominance of regional leaders who saw in centralism a huge risk to their own local hegemonic position. Thus, issues such as effective legal equality, economic freedom or the maintenance of the slavery system were not comprised in its agenda of priorities. And, as highlighted above, democracy was a

26 FAORO, Raymundo. Os Donos do Poder. Op. cit., p. 319. Original text: "O banho liberal, irradiado dos acontecimentos portugueses e brasileiros dos dois últimos anos, não permitia a passiva adoção do sistema absolutista.”

27 FAORO, Raymundo. Os Donos do Poder. Op. cit., p. 337.

28 FAORO, Raymundo. Os Donos do Poder. Op. cit., p. 320-321.

29 FAORO, Raymundo. Os Donos do Poder. Op. cit., p. 320-321. 
forbidden subject, evincing the profound social conservatism that pervaded this group (this and all others).

An anomalous liberalism, tied, refractory to social advances, conniving with slavery, focused on the State and not on the individual, led by groups that were economically dependent of State action. Moderates and Exalted, deep inside, shared the same source, which Faoro calls a restored liberalism, typical of the post-Napoleon French thought, plowed, among others, by Benjamin Constant. An ideology that believed in a political power "clean of despotic impurities" and able to act efficiently in defense of the order and the social stability. "The once merely negative character of liberalism, in an open strand since Montesquieu, would be denied, for the benefit of a mechanism to organize and build."30 31

In common, the three groups shared aversion to the people, defending without scandal the abolition of political citizenship not only to the slaves (about $1 / 4$ of the Brazilian population in 1820), but to the less privileged sectors. ${ }^{32}$ The thought of the French restoration, before defending freedom, prioritized social control, a notion that allowed to conceive a State disconnected of the popular will, giving rise to a broad and confused debate, which remained by the following decades and which can be synthesized in the dichotomy containment of power vs. State's protagonism. ${ }^{33}$

\section{The clash of ideas between the Constituent Assembly and the Emperor}

After the breakup with Portugal, it was time to draw up the first Brazilian Constitution. At least this was a point of consensus among all those involved in the organizing process of the State that arose, demonstrating that even the Absolutists were aware of the necessity of conforming to certain nineteenth century minimum standards.

The first Brazilian constituent process began even before the Independence, when the Prince Regent Pedro (later King Pedro I), edited the decree of June 3,

30 FAORO, Raymundo. Existe um Pensamento Político Brasileiro? Op. cit., p. 111. Original text: "O caráter outrora meramente negativo do liberalismo, em uma vertente aberta desde Montesquieu, seria negado, em proveito de um mecanismo a organizar e a construir."

31 It should be noted that, although minority members, there were representatives of a real political liberalism that obviously did not achieve prevail. As Octávio Tarquinio describes, "In the assembly of 1823 there were, and sincere, spirits bewitched by freedom, confident in its effects, animated by the conviction that sweetness and forgiveness are processes of governing men, at least as good and as effective as the hardness and violence." (Original text: "Na Assembleia de 1823 havia, e sinceros, espiritos enfeitiçados pela liberdade, confiantes nos seus efeitos, animados da convicção de que a doçura e o perdão são processos de governar os homens, ao menos tão bons $e$ tão eficazes como a dureza e a violência.")

SOUSA, Octávio Tarquínio de. Três Golpes de Estado. Op. cit., p. 31.

32 FAORO, Raymundo. Existe um Pensamento Politico Brasileiro? Op. cit., p. 109-110.

Octávio Tarquínio clarifies that in the early 1820 the population was estimated to be around 4 million, of which more than 1 million of slaves. SOUSA, Octávio Tarquínio de. Três Golpes de Estado. Op. cit., p. 21.

33 Relevant study on the subject, addressing current aspects, but certainly rooted in the debates here portrayed, can be find in: REIS, Fábio Wanderley. Estado liberal, projeto nacional, questão social. in Mercado e Utopia [online]. Rio de Janeiro: Centro Edelstein de Pesquisas Sociais, 2009. Available in SciELO Books <http://books.scielo.org> 
1822, convening a Luso-brasiliense Assembly, composed of deputies elected by the Provinces. ${ }^{34}$ With the formal separation from the metropolis, on September 7 , 1822 , the call made by the central government was not put into practice and, in the following months, the now Brazilian Emperor hesitated to install the Constituent Assembly. This fact generated major international pressures, with several countries refusing to recognize Brazil as an independent nation, and also internal tensions, especially between the liberal segments, when both Moderate and Exalted were fearful of a possible authoritarian reflux. ${ }^{35}$

Finally, in May 03, 1823, the Assembly was met (in fact, a constituent congress, because it also exercised ordinary legislative attributions), counting on several members who had participated in the Portuguese Constituent of 1822 and brought strong liberal ideas. ${ }^{36}$ There were 90 constituents, among which: “(...) Twenty-three were graduated in law, seven in canons, twenty-two were judges, nineteen were clergymen, being one bishop, three physicians, seven military, of whom three Marshals." 37

As Octávio Tarquínio explains, almost everyone had studied in Europe and accompanied with interest the unfolding of the debates and liberal struggles that swarmed in the European countries and in the American Continent. They were not, therefore, alienated from the great questions that permeated the State forming process, nor did they ignore the demands and needs of the country. ${ }^{38}$

There was a strong perception of the importance of that moment, as well as the responsibility that fell on the house: “(...) all the members of the Constituent and Legislative Assembly, from the most illustrious to the darkest, felt the importance of the investiture that consecrated them craftsmen of the constitutional pact of the new Empire, as legitimate representatives of the people (...)".39 Such notions, however, were certainly more an expression of liberal ideology in vogue than reflection of the Brazilian social reality.

Indeed, since the installation of the Constituent, and even in previous manifestations, Pedro I gave signs of rupture with any project of true Liberal meaning. In this context, it can never be forgotten the speech of the Emperor in his coronation (in the December 1 st, 1822), occasion in which he swore "(...) to

${ }^{34}$ LEAL, Aurelino. História Constitucional do Brasil. edição fac-similar. Brasília: Senado Federal, 2002. p. 48-50.

35 BONAVIDES, Paulo; ANDRADE, Paes de. História Constitucional do Brasil. Op. cit., p. 34. CASTRO, Araújo. A Constituição de 1937. edição fac-similar. Brasília: Senado Federal, 2003. p. 32-35.

${ }^{36}$ LEAL, Aurelino. História Constitucional do Brasil. Op. cit., p. 4 e 20.

37 SOUSA, Octávio Tarquínio de. Três Golpes de Estado. Op. cit., p. 21. Original text: “(...) vinte e três eram formados em Direito, sete em Cânones, vinte e dois eram desembargadores, dezenove eram clérigos, sendo um bispo, três médicos, sete militares, dos quais três marechais."

38 SOUSA, Octávio Tarquínio de. Três Golpes de Estado. Op. cit., p. 21.

39 SOUSA, Octávio Tarquinio de. Três Golpes de Estado. Op. cit., p. 19-20. Original text: “(..) todos os membros da Assembleia Constituinte e Legislativa, dos mais ilustres aos mais obscuros, sentiam a importância da investidura que os consagrava artífices do pacto constitucional do novo Império, como legitimos representantes do povo (...)" 
defend the Constitution that is to be made, if it is worthy of Brazil and me". ${ }^{40}$ About the theme, Nelson Nogueira Saldanha recalls:

\begin{abstract}
Historians always emphasize the way in which the Emperor, opening the works, asked for a Constitution at his level, that he would defend "if it were worthy of him" - which puts the eyes of the current critic before a difficult disagreement: or the judgment of the monarch would be the basis of the validity of the text, and then that assembly was not quite a constituent, or the Constitution to be draw would emanate from a legitimate power, founded in the people and exercised in authentic competence, and then the monarch, as an organ to be delimited in the letter of law itself, should only be accommodated. It's because we lived in the trance an unbearable combination. We had a sovereign on the throne and we wanted to have a liberal government: that William of Orange inside out intended to suit him our Bill. 41
\end{abstract}

The eminent conflict between the Emperor and the Deputies was already sensed, given the clearly centralizing and authoritarian posture of the ruler, dissonant of the beliefs in the limitation of the State power brought from the Lisbon Courts. And there was no way to refute the prominence of the Crown, in whose shadow the emancipation happened, making the young prince a direct participant of all events and first to be praised for the successes.

In spite of the resistance of several sectors that frontally criticized the increasingly evident Imperial authoritarianism, the fear of fragmentation remained firmly. For many liberal leaders, especially Moderate, “(...) the territorial extension of the country, the most democratic inclinations of the north in counter position with the southern tendencies, led many spirits (...) to doubt the possibility of organizing the vast Empire (...)".42 The yearning for political stability and social order spoke loudly, as well as the threats from the military forces, which instilled constant fear of violent intervention.

The signals issued by Pedro I, however, were not always clear. In the Speech of the Throne of 1823, addressed to the Constituent Assembly, after accepting to enter and remain in the enclosure where the constituents were assembled without the crown in his head (way of demonstrating no hierarchy between monarch and Assembly), the Emperor urged the members to draw up a "fair and

40 BONAVIDES, Paulo; ANDRADE, Paes de. História Constitucional do Brasil. Op. cit., p. 47. Original text: “(...) defender a Constituição que está para ser feita, se for digna do Brasil e de mim."

41 SALDANHA, Nelson Nogueira. História das Ideias Políticas no Brasil. Op. cit., p. 105. Original text: "Sempre os historiadores frisam o modo pelo qual o imperador, abrindo os trabalhos, pedia uma Constituição à altura, que ele defenderia 'se fosse digna dele' - o que põe os olhos do critico atual ante uma aporia dificil: ou o julgamento do monarca seria o fundamento da validade do texto, e então aquela assembleia não era bem uma constituinte, ou a constituição a fazer-se seria emanação de um poder legítimo, fundado no povo e exercido em competência autêntica, e então o monarca, órgão a ser delimitado na letra mesma da carta, só devia acomodar-se. É que vivíamos no transe uma combinação insustentável. Tínhamos um soberano no trono e queríamos ter um governo liberal: aquele Guilherme de Orange às avessas pretendia adequar a ele o nosso Bill."

42 SOUSA, Octávio Tarquínio de. Três Golpes de Estado. Op. cit., p. 22. Original text: “(...) a extensão territorial do país, os pendores mais democráticos do Norte em contraposição com as tendências do Sul, levaram muitos espíritos (...) a duvidar da possibilidade de organizar o vasto Império (...)" 
liberal Constitution". ${ }^{43}$ Would be merely symbolic adjectives or an acknowledgement of popular sovereignty translated into the Assembly?

Antonio Carlos de Andrada, the main constituent leader, was soon commissioned to remedy the doubt, transmitting specifically to the Exalted the monarch's message so that they meditate on their conduct, “(...) because the public opinion did not favor the Assembly and nothing would be easier for the Emperor, if they displeased him, to send them away." 44 To the power of the Emperor, however, the house confronted its own, which was reputed as a manifestation of the popular sovereignty.

The constitutional project elaborated by the Parliament, as expected, was impregnated by liberal thought, imposing restrictions on the monarchical power and strengthening the legislative representation, which rejected not only absolutism, but also the most conservative tendencies dominant since the Vienna Congress. "To remake the social pact, on new bases, by the free assent of all consenting individuals, this is what cradled the generous spirits of the time." 45 According to Nelson Saldanha:

\begin{abstract}
Agenor de Roure, in his meticulous and exhaustive Formation, it also shows how - by singularity, chance or irony of things - the English example was at every step copied in the progress of the works and in the proposals presented. Copied, moreover, with enthusiasms not similar to English behavior, with much verbiage and even with the intense inclusion of hurray and greetings in the published acts. ${ }^{46}$
\end{abstract}

The activities of the Assembly were marked by conflicts with the Emperor who, as the constituent project advanced and became clear its model, sought to make explicit its revulsion to the work led by the Andrada brothers, in particular Antônio Carlos de Andrada Machado. ${ }^{47}$

Naturally, as previously seen, radical measures were never been considered - or anarchistic, as used to be labeled at the time. In fact, Antônio Carlos (in spite of his participation in the frustrated Pernambuco Revolution of 1817, a rebellion with republican nature much closer to a European matrix liberalism), supported

43 COMPARATO, Fábio Konder. Prefácio. Op. cit., p. 9-10. Original text: “justa e liberal Constituição"

44 SOUSA, Octávio Tarquinio de. Três Golpes de Estado. Op. cit., p. 22-23. Original text: “(...) pois a opinião pública não favorecia a Assembleia e nada seria mais fácil ao Imperador, caso eles o desagradassem, como mandá-los embora."

45 SOUSA, Octávio Tarquínio de. Três Golpes de Estado. Op. cit., p. 25. Original text: "Refazer o pacto social, em bases novas, pelo livre consentimento de todos os individuos pactuantes, eis o que embalava os espiritos generosos da época."

46 SALDANHA, Nelson Nogueira. História das Ideias Politicas no Brasil. Op. cit., p. 105. Original text: "Agenor de Roure, em sua minuciosa e exaustiva Formação, mostra aliás como - por singularidade, acaso ou ironia das coisas - o exemplo inglês era a cada passo copiado no andamento dos trabalhos e nas propostas apresentadas. Copiado, de resto, com entusiasmos pouco ingleses, com muito palaureado e até com a feérica inclusão de vivas e saudações nos atos publicados."

47 BONAVIDES, Paulo; ANDRADE, Paes de. História Constitucional do Brasil. Op. cit., p. 77-78 e 81-82. The three brothers of the Andrada family played a prominent role in the process of Independence and followed actively participating in national political life over the early decades of the imperial regime. LEAL, Aurelino. História Constitucional do Brasil. Op. cit., p. 63. 
by his brother José Bonifácio, ${ }^{48}$ was herald of a conservative liberalism. The care with the maintenance of the social order, the fear of territorial fragmentation, the confidence in the monarchical authority as a connection element were shared values present in the constituent project.

It was necessary to avoid at all costs the horrors of France, with its fleeting constitutions, as well as "(...) the evils of 'unhappy Spain, swimming in blood' and 'disgraced Portugal'," cried out José Bonifácio. As Octávio Tarquínio explains, "José Bonifácio's speech revealed his conviction that Brazil could only be organized and endure with a strong government in the monarchical form."49

However, the notions of strength and centrality glimpsed by Pedro I went well beyond and were nourished by the continual action of a preponderant social segment: the rural producers, slave masters who feared for their property before the abolitionist thought of Bonifácio. The intervention of this group was decisive for his downfall of the ministry and immediate demonization, associating this clearly conservative thinker with the most negative there would be in terms of social reformism. 50

Understanding himself challenged in his authority, Pedro I reacted with increasing violence. On July 19, 1823, he edited a Proclamation whereby he opposed the device inserted in the constituent project which provided for the legislative veto to Emperor decisions. Claimed the monarch that “(...) some Chambers of Provinces of the north have given instructions to their representatives in which the democratic spirit reigns. Democracy in Brazil! In this vast and great Empire is absurd...". ${ }^{51}$

48 José Bonifácio de Andrada e Silva was vice-president of the São Paulo provisional board, formed in June of 1821 in the wake of the reflexes that the Porto Revolution produced in Brazil, and one of the main leaders of Independence. In January 1822 he was invited by Dom Pedro to compose his ministry, soon assuming undisputed prominence. There he remained until his fall in July of 1823, already in the wake of the crisis between the Crown and Constituent Assembly, and then took his chair in Parliament. He is known as the Patriarch of Independence. DOLHNIKOFF, Miriam. Introdução. in DOLHNIKOFF, Miriam (org.). José Bonifácio de Andrada e Silva. Projetos para o Brasil. São Paulo: Companhia das Letras, 2000. p. 4-5.

49 SOUSA, Octávio Tarquínio de. Três Golpes de Estado. Op. cit., p. 25-26. Original text: “(..) os males da 'infeliz Espanha, nadando em sangue' e do 'desgraçado Portugal'" "O discurso de José Bonifácio revelava a sua convicção de que o Brasil só se poderia organizar e perdurar com um governo forte, sob a forma monárquica."

50 SOUSA, Octávio Tarquínio de. Fatos e Personagens em Torno de um Regime. História dos Fundadores do Império do Brasil. São Paulo: Editora USP, 1988. p. 90-91. Octávio Tarquínio highlights the speech of Bonifácio, in which he Stated that 'blacks are men as we are.' And concludes: "Dangerous opinion at a time when the Brazilian economy rested in full in slave labor;(...)" This view sounded highly subversive, contrary to “(...) most immediate interests of the class in whose benefit preciously sued the political emancipation of Brazil - that of the rural landowners, the ruling class throughout the empire and a large part of the Republican period." (Original text: "Perigosa opinião num momento em que a economia brasileira descansava em cheio no trabalho escravo;(...)" Tal visão soava altamente subversiva, contrária aos "(...) interesses mais imediatos da classe em cujo beneficio precipuamente se processava a emancipação politica do Brasil - a dos proprietários rurais, classe dirigente durante todo o Império e larga parte do período republicano.")

51 CERQUEIRA, Marcelo. Notas à Constituição. Como foram convocadas as constituintes. Brasilia: Imprensa Nacional, 1985. p. 18. Original text: “(...) algumas Câmaras das Províncias do Norte deram instruções aos seus Deputados em que reina o espírito democrático. Democracia no Brasil! Neste vasto e grande Império é um absurdo..." 
A few days earlier, on May 5, Father Alencar had spoken at the Assembly denouncing the current state of repression:

\begin{abstract}
The government has taken violent and anti-constitutional measures, men have been arrested with no faults formed; others have been deported; opening up a wanton not only in court, but at the Provinces, which is nothing less than a political inquisition; the freedom of the press is almost over, if not in law, at least in fact. (...) The most prominent writers were deported or arrested; the spirits intimidated; many timorous, suspicious and wavering people; everyone was fearing, suspecting of despotism; the grief was general; and finally even the foreigners, who were among us, seemed to recognize and feel this truth. ${ }^{52}$
\end{abstract}

Lastly, after a sequence of public hits, the monarch dissolved the Assembly on November 12, 1823, forcing the parliamentarians' exit under the threatens of bayonet point. ${ }^{53}$ Finally the constituents were awakened from their dream: to implement a regime no more than moderately liberal, in which the popular sovereignty was recognized and the monarchical power - still quite wide subjected to the rule of law.

Liberal thinking failed to reformulate the State structure, it was unable to break the authoritarian and centralizing tradition inherited from Portugal. Finally, prevailed the King's precedence over the Constitution. ${ }^{54}$

\title{
3. The granted Constitution: authoritarianism in the Brazilian constitutional genesis
}

The Imperial decree that dissolved the Constituent Assembly predicted that a new body of legislators would be convened, which never happened. In fact, the task of drafting a Constitution was immediately assigned to the State Council, an Imperial advisory body created in the aftermath of the coup, what has been done under the leadership of the former constituent José Joaquim Carneiro de Campos. ${ }^{5}$ Once the text was concluded, it was forwarded for analysis in the Municipal Chambers, 56 which, under enormous pressure from the Emperor,

52 Padre Alencar. Speech at the Constituent Assembly. Apud SOUSA, Octávio Tarquínio de. Três Golpes de Estado. Op. cit., p. 28-29. Original text: “O governo tem tomado medidas violentas $e$ anticonstitucionais, tem-se prendido homens sem culpa formada; tem-se deportado outros; abrindose uma devassa não só na corte, mas pelas Provincias, que nada menos é que uma inquisição politica; a liberdade da imprensa está quase acabada, se não de direito, ao menos de fato. (...) Os escritores de maior nomeada estavam deportados ou presos; os espiritos aterrados; muita gente timorata, desconfiada e vacilante; temia-se, desconfiava-se do despotismo; o desgosto era geral; e finalmente até os estrangeiros, que estavam entre nós, pareciam reconhecer e sentir esta verdade.”

53 CASTRO, Araújo. A Constituição de 1937. Op. cit., p. 12.

54 FAORO, Raymundo. Existe um Pensamento Politico Brasileiro? Op. cit., p. 99.

55 BONAVIDES, Paulo; ANDRADE, Paes de. História Constitucional do Brasil. Op. cit., p. 74-75 e 77.

56 As Octaciano Nogueira explains, “(...) throughout the colonial regime, the Municipal Chambers were not political institutions, but simple administrative and judicial bodies, functions inherited from the Portuguese tradition (...)" (Original text: “(..) durante todo o regime colonial, as Câmaras Municipais não eram instituições politicas, mas simples órgãos administrativos e judiciários, funções herdadas da tradição portuguesa (...)") NOGUEIRA, Octaciano. Constituições Brasileiras. Op. cit., p. 31. 
proceeded to almost unanimous acclaim and the request for its immediate granting, that occurred in March 25, 1824.57

It's interesting to note that the 1824 Constitution fits quite rightly into the concept of conservative monarchical constitutionalism, established in the Vienna Congress and evident in the speech of the Moderates. So there are sharp connections between advances brought about by liberal thought and mechanisms that aimed at ensuring the maintenance of monarchical centralism whose prominence was indisputable and highlighted especially by the Moderator Branch, the role attributed to the State Council, the lifelong Senate and the complete submission of the Provinces. 58 The French constitutionalism, in its aspect present in the 1814 Constitution, granted by King Louis XVIII, was the great referential incorporated by the Brazil Empire. 59

As Faoro explains, "The organization of the Brazilian constitutional regime is not convertible (...) into liberalism. (...) It's project actually departed from another base: the Independence 'moderated by the national unity'."60 It was justified, therefore, the adoption of a strong government, a direct descendant of the Portuguese tradition born with the Marquis of Pombal, that placed the State at the center of the social organization. An absolutism with liberal paints that should please both the rural lords and the urban traders, but above all, designed to ensure the absolute protagonism of the monarchy. ${ }^{61}$

The Constitution called by Pedro I as 'twice more liberal', put into effect without debates or approval of the people's representatives, ratified what Faoro calls the reformist absolutism, a model that expresses a kind of official liberalism, expression that more than everything disqualifies the term liberal and its followers. ${ }^{62}$

In fact, the official discourse sought to emphasize the liberal nature of the text, removing all sorts of criticism that could cover it with the label of conservative, authoritarian or absolutist. "Either way, the Constitution was conceived liberally and liberally drafted," maintains Aurelino Leal, endorsing the Senate's Statement of December 20, 1823, according to which “(...) there could

57 CASTRO, Araújo. A Constituição de 1937. Op. cit., p. 12.

58 Text of the 1824 Constitution available in:

www.planalto.gov.br/ccivil_03/Constituicao/Constituicao24.htm

59 "Excluded the revolutionary models of France, Spain and Portugal, what is left? There remains the constitutionalism of the restoration of Louis XVIII, since it does not allude to the American system, rejected by the Republican content." (Original text: "Excluidos os modelos revolucionários da França, da Espanha e de Portugal, o que resta? Sobra o constitucionalismo da restauração de Luis XVIII, uma vez que não se alude ao sistema norte-americano, rejeitado pelo conteúdo republicano.”) FAORO, Raymundo. Existe um Pensamento Politico Brasileiro? Op. cit., p. 110 .

60 FAORO, Raymundo. Existe um Pensamento Politico Brasileiro? Op. cit., p. 108-109. Original text: "A organização do regime constitucional brasileiro não é conversivel (...) no liberalismo. (...) Seu projeto, na realidade, partia de outra base: a Independência 'moderada pela união nacional'."

61 FAORO, Raymundo. Existe um Pensamento Político Brasileiro? Op. cit., p. 108-109.

62 FAORO, Raymundo. Existe um Pensamento Politico Brasileiro? Op. cit., p. 111. 
not be a more liberal Constitution."63 It is difficult to understand the real meaning that the term had for these people or even the obsession to wield it.

An important actor of that time, someone situated in an opposite position to that occupied by the defenders of the regime, had an understanding that what was being built was simply an absolute monarchy. Friar Caneca saw in the absence of national representation a risk to any attempt to implant a State model immune to authoritarian tendencies. The liberalism that was said to be present in the Constitution of 1824 was, of course, not sustained "(...) in the "wake of the Locke, the Hamilton', the Spirit of the Laws."64 It was time, therefore, to exert the power of resistance, attribute inherent to the popular sovereignty, and overthrow the granted Constitution.

The constitutionalism was reduced to mere formality, emptying the sense of the Law as an instrument of control and restraint on political power. Order, social stability and national unity remained elevated to supreme values, tempered by a fragile nationalist feeling that, in truth, was primarily sustained in the rejection of the Portuguese element rather than in a sense of nation.

\section{THE LIBERAL THOUGHT SURVIVES: THE HOUSE OF DEPUTIES AS A SPACE OF RESISTANCE, THE COUP OF APRIL 07, 1831 AND A NEW BALANCE OF FORCES DURING THE REGENCY}

A phrase by Aurelino Leal accurately describes the institutional reality lived in the times that followed the granting of the 1824 Constitution: “(...) While there was no Constitution, there was more freedom than after its oath." 65

If in the period of independence Pedro I sought to transit between the different groups and ideologies, balancing between Moderate and Exalted liberals, without displeasing the Absolutists, after the fall of José Bonifácio and the crisis with the Constituent Assembly the Emperor turned his back on his first-time supporters, governing based in his personal charism. The rapid and voracious repression that followed evidenced what Faoro calls 'Saturn's terrible politics', which “(...) devours their own children, crushes the streets' leaders, the harmless declaimers, the disguised republicans and the genuinely liberal politicians who intended to submit the Emperor to the popular sovereignty."66

Pedro I had definitely incorporated the certainty that his power derived from the direct will of the people, such as defended José Bonifácio, to whom "(...) the nation embodied itself in its Emperor, charismatically united to the source of its

63 LEAL, Aurelino. História Constitucional do Brasil. Op. cit., p. 125-126. Original text: "Seja como for, a Constituição foi concebida liberalmente e liberalmente redigida" “(...) não poderia haver uma Constituição mais liberal”

64 FAORO, Raymundo. Existe um Pensamento Político Brasileiro? Op. cit., p. 98-99. Original text: “(...) na 'esteira dos Locke, dos Hamilton', do Espirito das leis.” Friar Joaquim do Amor Divino Rabelo, usually know as Friar Caneca (1779-1825)

65 LEAL, Aurelino. História Constitucional do Brasil. Op. cit., p. 146. Original text: “(...) enquanto não existiu Constituição, houve mais liberdade que após o juramento da Carta”

66 FAORO, Raymundo. Os Donos do Poder. Op. cit., p. 324. Original text: “(...) devora os próprios filhos, esmaga os lideres das ruas, os declamadores inofensivos, os republicanos disfarçados e os politicos genuinamente liberais que pretendiam submeter o imperador à soberania popular." 
sovereignty, prior to the assemblies."67 After all, the Constituent Assembly was installed by order of the Emperor to make a Constitution worthy of him; being dissolved the Assembly, Pedro I did nothing more than take back the sovereign power, attributed to him by the people when they proclaimed the Emperor a unique and undisputed leader.

These assurances, however, were certainly not shared by all the leaderships who survived the events of November 12, 1823. Successive imperial decrees suspending guarantees were issued, uninterrupted arrests and political and social repression erupted across the country. The individual freedoms, proclaimed in the chapter of the general provisions, did not represent more than a symbol of what was promised, which was still at most in a potential state, evidencing the symbolic nature of the Constitution.

Even a conservative author such as Aurelino Leal is peremptory in stating: “(...) the truth is that the constitutional regime was merely a label attached to the absolutism." 68 And if any doubt could remain in this, the Emperor himself enlighted it by proclaiming, in the preamble to the Imperial Decree of November 17,1824 , wishing "(...) that all the inhabitants of this Empire enjoy, as much as possible, the benefits of the Constitution." 69

In view of this reality, it was natural that soon the monarchical centrality and the unitary State model adopted became uproar object.

After the violent stage circumscribed between the period of conflicts with the Constituent Assembly and the installation of the first parliamentary term, the critique of the monarchical regime was organized and consolidated. From May, 1826, the Parliament (in particular the House of Deputies, although there have been eventual and decisive Senate's interventions) has assumed the position of institutional resistance to the systematic breach of the Constitution.

Absolute novelty, the Parliament saw itself as a conquest of all Brazilians who thus became lords of their own destiny. ${ }^{70}$ The liberal spirit quickly return to manifest itself. Moderate liberalism, restrained, refractory to social reforms, increasingly distant from its incendiary European roots, but concerned with setting boundaries to the monarchical power and asserting the Parliament authority. The popular prestige of the legislative house grew as the Emperor's declined, reinforcing itself when looking with increasing intensity for provincial and municipal life, assuming the defense of autonomy and local enhancement, maneuvre that allowed to co-opt the support of the rural lords. ${ }^{71}$

67 FAORO, Raymundo. Os Donos do Poder. Op. cit., p. 326. Original text: “(...) a nação se corporifica no seu imperador, unido carismaticamente à fonte de sua soberania, anterior às assembleias."

68 LEAL, Aurelino. História Constitucional do Brasil. Op. cit., p. 146. Original text: “(...) a verdade é que o regime constitucional não passava de um rótulo colado ao absolutismo."

69 Imperial Decree of November 17, 1824. Apud LEAL, Aurelino. História Constitucional do Brasil. Op. cit., p. 149. Original text: “(..) que todos os habitantes deste Império gozem já, quanto possivel for, dos benefícios da Constituição."

70 CALDEIRA, Jorge. Introdução. in CALDEIRA, Jorge (org). Diogo Antonio Feijó. Coleção Formadores do Brasil. São Paulo: Editora 34, 1999. p. 12.

71 FAORO, Raymundo. Os Donos do Poder. Op. cit., p. 340. 
It began a new stage in the struggle for power, now clearly polarized between the Crown and the Parliament. As the reformist discourse consolidated itself, became necessary a new State in which authoritarianism was replaced by liberalism, an anomalous liberalism, however, capable of accept and live with the exclusion. Illustrative are the words of Hipólito José da Costa, an important spokesman of the liberal cause: "No one desires more than us the useful reforms; but no one bothers more than us, that these reforms are made by the people; because we know the bad consequences of this way of reforming; we wish the reforms, but made by the government (...)"72 How strong was the Marquis of Pombal legacy!

The political crisis was spreading at the same time when the Emperor lost support both between the traditional elites and the people. The conflicts raged, which opened space for more radical solutions: on the arrival of the 1830's it was already spoken in revolution, as it is read in the manifesto of Evaristo da Veiga, then Deputy: "(...) let everything that is necessary be done, but avoid the revolution."73

And so, amid pressures for the slowdown of the regime, which included demands such as the extinction of the Moderator branch and the State Council, the reform of the Senate to end the lifelong mandates, the granting of greater autonomy to the Provinces and the municipalities and, in the voice of some, even the adoption of a Republican regime, came to an end the short reign of Pedro I. Pressed by the political crisis and tempted to continue his personal project of power in Portugal, whose throne recently wandered with the death of his father, King João VI, on April 07, 1831 the Emperor abdicated after mere nine years of government.

The abdication, in the reading of Octávio Tarquinio, was more than a mere ideological clash between absolutists and liberals. In fact, it represented the true political emancipation of Brazil, finally paving the way for the country to determine its future, detached from the Portuguese heritage: "The April 07 was undeniably a liberal movement complicated by nativist resentment."74

One of the main leaders of the movement and active figure during almost the entire period of the Regency, Diogo Antônio Feijó clearly translated the desired goals. Fierce critic of what he classified as imperial authoritarianism and false liberalism preached by the deposed regime, in his speeches he repudiated the arbitrary prisons, the despotism, the privileges of the wealthy and powerful, the abandonment to which the poor were relegated, the distribution of public positions as a form of co-optation of government support. He preached a government that eliminated the countless remnants of the old Portuguese order,

72 Hipólito José da Costa. Apud FAORO, Raymundo. Existe um Pensamento Politico Brasileiro? Op. cit., p. 109. Original text: "Ninguém deseja mais do que nós as reformas úteis; mas ninguém aborrece mais do que nós, que essas reformas sejam feitas pelo povo; pois conhecemos as más consequências desse modo de reformar; desejamos as reformas, mas feitas pelo governo (...)"

73 Evaristo da Veiga. Manifesto published in the newspaper Aurora Fluminense. Apud LEAL, Aurelino. História Constitucional do Brasil. Op. cit., p. 162-163. Original text: “(...) faça-se tudo quanto é preciso, mas evite-se a revolução."

74 SOUSA, Octávio Tarquínio de. Três Golpes de Estado. Op. cit., p. 84. Original text: “O 7 de abril foi incontestavelmente um movimento liberal complicado de ressentimento nativista." 
building in its place a Brazilian State model, where there was room for social and regional inclusion, always with mainstay in the constitutional order. ${ }^{75}$

The consensus between Moderate and Exalted liberals, however, lasted little and soon three groups were again in conflict, following the unresolved clashes at the time of independence. The Absolutist reactionaries deified the fallen regime, trying to restore it integrally, including the return of Pedro I; the Exalted ones flirted with the Republic, repudiated the institutions most strongly connected with the monarchical protagonism and defended the administrative decentralization to the Federation; the Moderate already understood enough to correct the State's direction, expurgating the authoritarian elements without, however, opening space for radicalisms and social anarchy. ${ }^{76}$

Soon all presented themselves to occupy the empty throne, beginning a new cycle of conflicts, now aggravated by the attitude of the military, active agents in the movement of April 07, 1831 and who followed frankly insubordinate. Disorder and anarchy - so repeated terms at that time - were constant threats, emerging in the Provinces movements of contestation that aimed primarily at the strengthening of local power. ${ }^{77}$

The leadership exercised by the House of Deputies on April 07, wielding the flag of liberalism, did not signify a popular empowerment. Instead, the representative system sought to disconnect from the people, trying to ensure the elite's protagonism: "The revolutionaries thus turned, from one moment to another, into conservatives, almost reactionaries (...)"78

The arena of disputes remained concentrated in the Chamber of Deputies, which assumed, between 1831 and 1840, the centrality of the decision-making process. And quickly the Moderate group managed to consolidate itself as a sufficiently solid majority to take over the Executive branch, through the Regency, and contain the revolutionary wave that was announced, but never fulfilled.

And once again the fluidity of liberal convictions became evident. Controlling the Regency, the moderated leaderships distanced themselves from many of their claims related to the containment of political power. Wielding the flag of order, they were involved in fighting against what they saw as anarchy, or, in other words, any proposal that could jeopardize the interests of the dominant rural elite. The drama of Brazilian liberalism became clear: “(...) ideology of opposition, destructive, unable to govern according to it's program, transformed, once at government, in conservative, with the same vices, with equal despotism to the substituted party."79

75 CALDEIRA, Jorge. Introdução. Op. cit., p. 14.

76 SOUSA, Octávio Tarquínio de. Três Golpes de Estado. Op. cit., p. 83.

77 SOUSA, Octávio Tarquínio de. Três Golpes de Estado. Op. cit., p. 84.

78 FAORO, Raymundo. Os Donos do Poder. Op. cit., p. 345. Original text: “Os revolucionários passavam assim de um momento para outro a conservadores, quase a reacionários (...)”

79 FAORO, Raymundo. Os Donos do Poder. Op. cit., p. 345. Original text: “(...) ideologia de oposição, demolitório, incapaz de governar de acordo com seu programa, transformado, no poder, em conservador, com os mesmos vícios, com igual despotismo ao do partido substituido." 
The arm wrestling between Regency and Chamber of Deputies followed, seeking the Exalted, strongly present in the Parliament (albeit without composing majority), mark a position in defense of an agenda that had as central project the provincial autonomy. Such polarization between Moderate and Exalted worsened especially from 1834, when the death of the former Emperor put an end to the dreams of restoration, hopelessly emptying the current of the Caramurus. ${ }^{80}$

The challenge for the Moderate was to contain the federalist movement and the popular mobilizations, very alive in the Provinces and heavily connected with the struggles for local autonomy, which, by the way, gave rise to several revolts, including some with separatist nature. The breaking of unity and the arrival of the people to government power were the main threats against which the Regency proposed to fight. 81

\section{THE ADDITIONAL ACT: INTRODUCTORY NOTES AND ESSENTIAL ASPECTS OF A DECENTRALIZING EXPERIENCE}

The Regency did not have the strength to confront the conflicts that followed particularly at the north of the Court and the country's southern end. It was not only political reasons, resulting from successive disputes for power, but also the extreme economic fragility to foster a climate of dissatisfaction in practically all regions. In the reading of Celso Furtado, the numerous armed rebellions that erupted reflected the process of general impoverishment and, especially, of the central government. ${ }^{82}$

The strength of the provincial leadership, usually closely linked to the rural lords, if it did not lead the country to a federalism of North American orientation, certainly allowed to reverse the prevailing conception of the structure of power. And here we have a curious note, which illustrates the fluidity of the ideological convictions of the main political actors: if in 1823 the rural owners were the main responsible for the overthrow of José Bonifácio, strengthening the authoritarian project of Pedro I, from 1831 onwards they allied themselves with Exalted liberals and their objective of political and administrative decentralization.

And so, for three years, in the midst of which there was still a frustrated coup attempt, major constitutional changes were being negotiated, always aiming at the implementation of the liberal decentralizing project. Despite the division

It's relevant to bring, on this issue, the prudently conservative note of Aurelino Leal, counterpoint to the vision of Raymundo Faoro, saluting the predominance (albeit partial) of the Moderates: "For the happiness of the country, the government has fallen into the hands of the Moderate Liberals: in Press, stood out Evaristo; in the high administration appeared figures like that of Feijo (...) The Moderates' work consisted in containing the ultra liberal tendencies and aspirations of all the exalted." (Original text: "Para felicidade do pais, o Governo pairou às mãos dos liberais moderados: na imprensa, sobressaiu Evaristo; na alta administração apareceram vultos como o de Feijó (...) O trabalho dos moderados consistiu em conter as tendências e aspirações ultraliberais de todos os exaltados.") LEAL, Aurelino. História Constitucional do Brasil. Op. cit., p. 166.

80 Caramuru was the nickname attributed by the Tupinambás Indians to the Portuguese navigator Diogo Álvares, who shipwrecked on the Brazilian coast in 1510, and means Son of Thunder or Sea Dragon. At the earlier XIX century, nominated the supporters of the King Pedro I.

81 FAORO, Raymundo. Existe um Pensamento Politico Brasileiro? Op. cit., p. 153.

82 FURTADO, Celso. Formação Econômica do Brasil. Op. cit., p. 146-147. 
between Moderate and Exalted, the House of Deputies, faithful to the motives that led it to head the movement of April 07, soon took the initiative of drafting concrete proposals to restructure the State. The Moderate sought, first of all, to proceed with the reforms in order to contain the Exalted pressure and provincial riots, in addition to dealing with the still threatening presence of the Caramurus restorers.

The Chamber's first attempt to approve a package of measures that included the extinction of the Moderator branch and the Council of State, the restructuring of the Senate and the granting of a series of decision-making prerogatives to the Provinces was barred by the Senate, a space still dominated by a conservatism that flirted with the absolutist tradition. ${ }^{83}$ A new action would take about a year, period during which it was gestated what could have been the second coup d'état of the decade, that had barely begun.

On July 30, 1832, once again the House of Deputies in conjunction with the Regency, started a movement that aimed to adopt a new constitution, known as Constitution of Pouso Alegre. This was not effectively an original text, but a broad review of the charter of 1824 that “(...) it substantiated the average of the best and most enlightened liberal opinion of the moment, the thought of the 'moderates', in spite of certain dispositions that would be said of 'exalted' hue." 84 Much of what was proposed in Pouso Alegre compounded the reform package approved by the House and rejected by the Senate in the previous year. The option by the coup d'état illustrates how serious and founded were the fears that the Senate would oppose an almost unbridable barrier to the progress of constitutional reform. ${ }^{85}$

In just over 24 hours, the fury of the coup was cooled without any concrete conquest. It left in its wake, however, the certainty about the need for the debate on the State reform to be carried forward, with began the path that would culminate in the approval of the Additional Act. ${ }^{6}$ Given the animosities between deputies and senators, struck by the frustrated movement, there was a curious agreement between the two houses through which it was established that it would be let to the next legislature to discuss and approve the intended reforms, according to predefined terms. ${ }^{87}$

Finally approved on August 12, 1834, the Law n. 16, known as the Additional Act, represented the conciliation between unitary and decentralizing tendencies, an attempt to balance between greater decision-making autonomy for

83 LEAL, Aurelino. História Constitucional do Brasil. Op. cit., p. 168.

84 SOUSA, Octávio Tarquínio de. Três Golpes de Estado. Op. cit., p. 103. Original text: “(...) consubstanciava a média da melhor e mais esclarecida opinião liberal do momento, o pensamento dos 'moderados', malgrado certas disposições que se diriam de matiz 'exaltado'."

85 SOUSA, Octávio Tarquínio de. Três Golpes de Estado. Op. cit., p. 105.

86 "The turnout of the majority of the Chamber was evident: after the night well or poorly slept, no 'great measure', no 'extraordinary measure' would be more possible: only half measures, soft solutions, conciliatory measures. And that's what happened." (Original text: "A reviravolta $d a$ maioria da Câmara era evidente: depois da noite bem ou mal dormida, nenhuma 'medida grande', nenhuma 'medida extraordinária' seria mais possivel: só meias medidas, soluções mansas, medidas conciliatórias. E foi o que aconteceu.") SOUSA, Octávio Tarquinio de. Três Golpes de Estado. Op. cit., p. 98.

87 LEAL, Aurelino. História Constitucional do Brasil. Op. cit., p. 173-174. 
the Provinces with the maintenance of the central government hegemony. "The Additional Act, ripped out not from convictions but to fear of moderates, seeks to organize a power beam, concentrated in the Provinces, of whose covenant the Empire would be stablished." 88 The leadership of the moderated liberals allowed them to co-opt the farmers and large slave's lords, guaranteeing those a reasonable base of local support, which allowed them to stay ahead of the Regency for the following years.

The protagonism of this current can be attributed, once again, to the search for order and social stability, permeated by a spirit of compromise, which spread amid the fatigue of so rough fights. ${ }^{89}$ Even though brandishing the liberalism flag, the Moderates placed above many of their promises, wielded in 1831, the defense of territorial integrity, the command unit before the factions in dispute: "Liberals, actually, in defensive against the doctrines that were feeding them, refugees (...) in the dictatorship, defenders of the ministerial responsibility transformed into ministers irritated by the criticism of their performance." 90

The typical self-government of the federations was not granted to the Provinces, but the legislative autonomy and the broad ascendency about the municipalities played a similar role, especially in the absence of clarity about the responsibilities that each entity would fit. The large grey zones that emerged in the relations between municipalities, Provinces and central power have opened up a margin for even more conflicts. ${ }^{91}$

Another consequence of the model adopted was the granting to local lords of a broad and almost unrestricted authority, eventually making the municipalities the headquarters of the decision-making process. This is because the police and justice were handed over to the municipal jurisdiction, which conferred on the rural aristocracy, the holder of political power, the complete social control, in what was called Caudilhismo. ${ }^{92}$ As Faoro explains, the judges of peace, first judicial instance and chosen according to the convenience of the lords,

88 FAORO, Raymundo. Os Donos do Poder. Op. cit., p. 354. Original text: “O Ato Adicional, arrancado não às convições mas ao medo dos moderados, procura organizar um feixe de poderes, concentrados nas Províncias, de cuja aliança se firmaria o Império."

89 SOUSA, Octávio Tarquínio de. Três Golpes de Estado. Op. cit., p. 111.

90 FAORO, Raymundo. Os Donos do Poder. Op. cit., p. 350. Original text: "Liberais, na verdade, em defensiva contra as doutrinas que os alimentavam, refugiados (...) na ditadura, defensores da responsabilidade ministerial transformados em ministros irritados pelas criticas sobre sua atuação."

It is in the same sense the reading made by Octavio Tarquinio about the movement adopted by the Moderates: "Without authority, without stable central government, nothing would be resolved, since the maximum problem consisted of the guard of the national unit, threatened from all sides." (Original text: "Sem autoridade, sem governo central estável, nada se resolveria, visto que o problema máximo consistia no resguardo da unidade nacional, ameaçada de todos os lados.") SOUSA, Octávio Tarquínio de. Três Golpes de Estado. Op. cit., p. 111-112.

91 FAORO, Raymundo. Os Donos do Poder. Op. cit., p. 355.

92 "In the Provinces, the territorial influences, families and coalitions of farmers, express their will by means of caudilhos, lords of the assemblies and municipalities." (Original text: "Nas Províncias, as influências territoriais, famílias e coligações de fazendeiros, expressam sua vontade por meio de caudilhos, senhores das assembleias e dos municipios.") FAORO, Raymundo. Os Donos do Poder. Op. cit., p. 363. 
constituted the center of the domination system, “(...) perhaps the third authority after the Regency and the ministers."93

Violence was the rule in the relations between local governments and citizens, in a context in which the power that the caudilhos had so far exerced on their farms overflow the fences and, once transformed into lords of justice and police, began to affect the entire population. ${ }^{94}$ In fact, the logic of power in the municipalities was strongly connected to the dominance structure prevailing in the ranches, where a mass of slaves lived under the exclusive control of the masters, constituting a wide population layer in the margins of the State's authority. The mastership, now with legal support, extended even to the free men who lived in their domains, a space beyond the official law. 95 And so they lived, with a certain approval of the central government, the legal Brazil and the real Brazil.

Frustration and fear were feelings that quickly dominated many Moderates who had acquiesced with the Additional Act. Once again, the fear of anarchy and the ruin of the national unity were shouted. Regional antagonisms, territorial and tax disputes, in addition to the already traditional tendency to confront the central government have frightened the Regency and much of the Parliament. Already in 1836 it was repeatedly spoke up to contain the prerogatives granted to the Provinces, fruit of the fear before the strengthening of the rural lords. Interestingly, the discourse that gradually consolidated did not complain about the repeal of the Act, but its interpretation, euphemism that seemed to meet the conciliatory project pursued by the Conservatives. ${ }^{96}$

In the end, centralism was taking back its space. At the moment when the wave stirred in 1831 had been defeated and the threat of restoration excised, the environment favorable to the reforms was dismantled, and the country settled around the conserving structures forged in 1824 .

\section{THE MYTH OF THE THRONE: THE INTERPRETATION LAW OF THE ADDITIONAL ACT, THE COUP OF LEGAL AGE AND THE STABILIZATION BASED ON THE CONSERVATIVE PROJECT}

The new arrangement of forces which was consolidated after 1834 led to the final split between the liberals, finally organized in the two parties that would polarize the political clashes for decades. The Conservative Party, formed by the Moderates, remained faithful to the principles of State organization current in the period previous to the Regency: centralization, resistance to the reforms,

93 FAORO, Raymundo. Os Donos do Poder. Op. cit., p. 353. Original text: “(...) talvez a $3^{a}$ autoridade depois da Regência e dos ministros”

94 FAORO, Raymundo. Os Donos do Poder. Op. cit., p. 353-345.

95 The Stately domain did not extend only to free men, but also to women and children, especially orphans who, after the age of 7 years, were handed over to the guardianship of the municipal councils and, as a rule, ended informally incorporated into families and subject to forced labor on farms or houses. WAQUIM, Bruna Barbieri; COELHO, Inocêncio Mártires; GODOY, Arnaldo Sampaio de Moraes. A história constitucional da infância no Brasil à luz do caso do menino Bernardino. Revista Brasileira de Direito. Passo Fundo, vol. 14, n. 1, Jan./Abr. 2018. p. 93.

96 LEAL, Aurelino. História Constitucional do Brasil. Op. cit., p. 179-181. 
reestablishment of the State Council, Moderator branch and, especially, the conviction that the Emperor reigns, governs and administers. ${ }^{97}$ Finally this group openly adhered to the project of the conservative constitutionalism which has always defended.

On the other hand, the Liberal Party congregated the Exalteds and their defense of the postulates of popular sovereignty, of the monarchy (if not federative at least decentralized), of the elective Senate and the end of the Moderator branch. Firmly on its contained liberalism, remained refractory to social or economic reforms that could jeopardize the statist model inherited from Portugal. ${ }^{98}$ Liberalism and monarchism, therefore, have been combined almost naturally, either because of the dependence relationships present between the productive forces and the government, either by the popular aspirations (or at least of an elite that surrounded the Court) for stability. 99

For both groups, the vision of the monarchy as an agglutinating and mainstays against republican pretensions, synonymous with fragmentation and anarchy, followed on the horizon. The mystique of the throne enchanted everyone, disconnected from the partisan boundaries, present in the national subconscious, especially of the dominant classes. What many considered liberal excesses, possible thanks to the weakness of the Regency, would only be corrected with the restoration of the authority centered on the monarch. ${ }^{100}$

It was time to put definitive brakes on the democratic aspirations that some have dared to desire, restore the social hierarchy through the cloistering of the spaces of power. The ruling classes continued to share the desire not to be subjected to what they considered the tyranny of the masses, faithful to the conservatism of Constant, Tocqueville and Montesquieu so well translated into the notion, already presented, of monarchy without despotism and freedom without anarchy. ${ }^{101}$

The first act of the play that Liberals and Conservatives began to stage was the approval of the Law n. 105, of May 12, 1840, nicked of Interpretation Law of the Additional Act. Fruit of the project presented on July 10, 1837, by the Conservatives, under the decisive leadership of Bernardo Pereira de Vasconcelos, its slow processing reflected the concert of forces between these two groups. The resistance of the Liberals served to reaffirm their commitment to administrative political decentralization and certainly translated the desire to attract the rural lords to their side. Conservatives, for their part, although they counted with relative majority and controlled the Regency, feared the direct confrontation that could upset them with the caudilhos.

In this fragile equilibrium in which the Conservative government was sustained it was not appropriate to revoke the Additional Act. Hence the path of euphemism was adopted: instead of derogating, interpreting. ${ }^{102}$ And so was

97 FAORO, Raymundo. Os Donos do Poder. Op. cit., p. 369-370.

98 FAORO, Raymundo. Os Donos do Poder. Op. cit., p. 370.

99 SALDANHA, Nelson Nogueira. História das Ideias Politicas no Brasil. Op. cit., p. 107.

100 SOUSA, Octávio Tarquinio de. Três Golpes de Estado. Op. cit., p. 118.

101 FAORO, Raymundo. Existe um Pensamento Politico Brasileiro? Op. cit., p. 158.

102 LEAL, Aurelino. História Constitucional do Brasil. Op. cit., p. 182. 
conceived the project whose task would be elucidate the terms of the Additional Act, limiting several of the prerogatives granted to the local authorities. ${ }^{103}$ The Provincial Assemblies, local center making, were emptied in favor of the central Legislative branch. The control over the police and the concession of jobs and public offices, an important bargaining mechanism, returned to the Court, disarticulating two foundations of provincialism. ${ }^{104}$

The difficult processing of the project was finally unlocked by the Liberals when they assumed the leadership of the final movement that would end the proto-republican adventure of the Regency. Glimpsing the possibility of finally taking for itself the government, this group prepared the ground to allow the restoration of full authority to the central power. ${ }^{105}$ And at this moment, once again, the anomalous liberalism present in Brazil gave the solution's tone sewn by several hands.

Although not coherent with the liberal agenda, the movement led for these group became a struggle against the Regency and the Conservative, owners of power since the failure of the 1832 coup d'état: "Anticipated legal age was the easy road that would open to liberals access to power." 106 It is important to mention that, despite the initiative of the Liberals, the movement for the anticipation of the throne inheritor's legal age was already disseminated and was recognized by the most varied sectors of society as the only way to restore national stability.

Proof of this was the protagonism assumed by the Senate, still in 1840 a conservative bastion, almost reactionary. In the words of Octávio Tarquinio:

The first truly revolutionary act came from the Senate, underneath the initiative of Marquis of Paranaguá, its President (...). This is when the conventions of legality have been broken, so often threatened since the dawn of the legal age campaign; there began the parliamentary revolution processed in a few hours. 107

Relying on the acquiescence of the new Emperor, the support of the military and the sympathy of the people, the constitutional legality was easily abandoned, through an act of acclaiming, to assign the throne immediately to Pedro II. The

103 For example, the arrangement contained in article $4^{\text {th }}$, which restricted the possibility of sanctioning magistrates, prerogative previously granted to Provincial Legislative Assemblies: “Art. $4^{\text {th }}$. In the word - Magistrate - that uses art. 11, 7 , of the Additional Act, the members of the Relations and Superiors Tribunals are not comprised." (Original text: “Art. 4". Na palavra Magistrado - de que usa o art. 11, $\S 7^{\circ}$, do Ato Adicional, não se compreendem os Membros das Relações e Tribunais Superiores.') NOGUEIRA, Octaciano. Constituições Brasileiras: 1824. Op. cit., p. 116.

104 FAORO, Raymundo. Os Donos do Poder. Op. cit., p. 379.

105 LEAL, Aurelino. História Constitucional do Brasil. Op. cit., p. 181-182.

106 SOUSA, Octávio Tarquinio de. Três Golpes de Estado. Op. cit., p. 125. Original text: “A maioridade antecipada era a estrada fácil que abriria aos liberais o acesso ao poder."

107 SOUSA, Octávio Tarquínio de. Três Golpes de Estado. Op. cit., p. 136. Original text: "O primeiro ato propriamente revolucionário foi do Senado e de iniciativa do Marquês de Paranaguá, seu presidente (...). Ai é que se romperam as convenções da legalidade, tantas vezes ameaçadas desde os primórdios da campanha maiorista; ai começou a revolução parlamentar processada em poucas horas." 
rapid coup against the Regency begun on the morning of July 22, 1840, and was concluded on the following afternoon with the oath of the monarch, when he committed to maintaining the Catholic religion, the territorial integrity of the country and to obey and enforce the Constitution. ${ }^{108}$ With caveat, certainly, to article 121, which determined to be the Emperor "(...) underage until the age of eighteen years."

The regime that emerged was a direct result of the ambiguities of national liberalism, always disconnected from its revolutionary and challenging social roots and very dependent on State action. The arrangement between the Crown and the Legislative branch gave rise to a parliamentarism without people, with party organizations previously engaged in grooming and coercing the electorate, firm in the defense of the oligarchic interests that have always determined the direction of the country. ${ }^{109}$

With the two main partisan groups linked to the Emperor and eager to make themselves hegemonic by their intermediation, soon the rapid process of the country stabilization came into motion, always aiming the strengthening of the monarchical authority. Concrete measure quickly carried out, possible thanks to the rearrangement of forces, was the reform of the Criminal Procedure Code through the law of December 3, 1841, which suppressed several prerogatives granted to the municipal rulers and that allowed the caudilhos' thugs to act in the cities as they did on the farms. ${ }^{110}$

The local leaders, of course, did not disappear, but were tied to the central government, dependent on the party that occupied the ministry: "The henchmen of the territorial lords are the Empire's henchmen, led by the presidents of Provinces and their agents. Over the hinterlands and the fields descends the Imperial sword (...)"111 In return, because fear itself would not be able to contain the rural elite autonomic pretensions, commendations and nobiliarchical titles were largely distributed, as well as the uniform and the patents of the National Guard, transforming the caudilhos into colonels, the Emperor's armed long arm. ${ }^{112}$

Once the threats from the Provinces were controlled, the political parties coopted, and silenced the people, the conservative march was complete and the splendor of the royal throne overshadowed any contestatory pretension. Protected by the State Council and supported in the Senate, the Emperor, with few acts, reestablished decision-making centralism and emptied the liberal agenda. The political elites began to occupy a space under the lights of the stage illuminated by the monarchy, while the audience watched in the dark the spectacle played by the dome of the social structure.

108 SOUSA, Octávio Tarquínio de. Três Golpes de Estado. Op. cit., p. 139-141.

109 FAORO, Raymundo. Os Donos do Poder. Op. cit., p. 371.

110 On the Penal Code of the Empire of 1830, and its subsequent amendments, see WAQUIM, Bruna Barbieri; COELHO, Inocêncio Mártires; GODOY, Arnaldo Sampaio de Moraes. A história constitucional da infância no Brasil... Op. cit., p. 95.

111 FAORO, Raymundo. Os Donos do Poder. Op. cit., p. 383. Original text: "Os capangas dos senhores territoriais passam a ser capangas do Império, conduzidos pelos presidentes de Provincias e seus agentes. Sobre os sertões e os campos desce a espada imperial (...)"

112 FAORO, Raymundo. Os Donos do Poder. Op. cit., p. 386. 
The liberal project, in theory shared by both Conservatives and Liberals, led by the political winds, ended up proving incapable of imposing itself on the Portuguese tradition. The authoritarian rancid was too strong and was too adhered to the minds of all the main actors who participated in the plot so far described and analyzed. All the power emanates from the king; the people are a threat to be restrained; freedom must be given with caution; democracy is synonymous with anarchy. These are statements that translate the ideology of the dominant elites in these early twenty-first years of Brazilian institutional life and that annihilate any attempt to incorporate a truly transformative political liberalism.

Javier Fernández Sebastián, in a recent study in which he seeks to revisit the frequent criticism of the nineteenth century Latin American liberalism, questions the negative view that historiography, especially with Eurocentric orientation, has built. He maintains that the challenges experienced in these countries impose a different reading to the liberal postulates, and it is not reasonable to expect the governments of the Spanish and Portuguese Americas to follow the same political and moral framework of Europe that, by the way, in the same period also was faltering in applying a pure political liberalism:

It is evident, moreover, that the first Ibero-American liberals had to face great challenges, comparatively much larger than those of their northern neighbors. Suddenly, they had to set up new institutions to govern and administer enormously heterogeneous populations that lived scattered in immense territorial extensions, under very diverse climates and living conditions. They also found themselves in a paradoxical situation: they had to apply all their inventiveness to the creation and strengthening of the new States and, at the same time, as liberals, they wanted to circumscribe and limit their powers $(\ldots)^{113}$

In fact, European liberal thinking would be, for the Latin America countries, something like an 'exotic plant', consisting of ideas largely incompatible with the reality lived on this side of the Atlantic. Sebastian thus synthesizes his inconformism:

How does an ideology invented in Europe, conceived by and for Europeans - including the Europeans transplanted to the anglophone America - be able to regulate and govern multi-ethnic societies and with large indigenous populations, as diverse and as complex as those of the Spanish and Portuguese Americas? 114

113 SEBASTIÁN, Javier Fernández. Introducción. En busca de los primeros liberalismos iberoamericanos. in SEBASTIÁN, Javier Fernández (org.) La Aurora de la Libertad. Los primeros liberalismos en el mundo ibero-americano. Madrid: Marcial Pons Historia, 2012. p. 10-11. Original text: "Es evidente, por lo demás, que los primeros liberales iberoamericanos tuvieron que hacer frente a grandes desafios, comparativamente mucho mayores que los de sus vecinos del norte. Por de pronto, tuvieron que poner en pie nuevas instituciones para gobernar y administrar poblaciones enormemente heterogéneas que vivian diseminadas en inmensas extensiones territoriales, bajo climas y condiciones de vida muy diversos. Se encontraron además en una situación paradójica: tenian que aplicar todo su ingenio a la creación y al robustecimiento de los nuevos Estados y, al mismo tiempo, en tanto que liberales, deseaban circunscribir y limitar sus poderes (...)”

114 SEBASTIÁN, Javier Fernández. Op. cit., p. 12. Original text: “CCómo una ideología inventada en Europa, pensada por y para europeos - incluyendo los europeos trasplantados a la América anglófona -, podia servir para regular y gobernar sociedades multiétnicas y con amplias 
The perspective presented by the author is very close to the facts brought and analyzed in this missive. A more detained look at the way in which political and economic spaces were related in the Brazilian Empire actually allows to perceive how the theoretical postulates of liberalism were suffocated by a reality that barely resembled the European system. What once again justifies the question: why so much attachment to the word liberal, even in the moments of greater conservatism?

The following twenty years marked the consolidation of the strong government, with an Executive branch hegemonic and permanently concerned to restrict the decentralizing glimpsers from the Provinces. It is certain that the demands for local autonomy did not disappear, as the criticism to the Moderator branch or to the various instruments, legal or not, that allowed the continuity of the authoritarian model. The Liberal party itself continued for decades sustaining similar flags, although, on all occasions in which it came to compose the ministerial cabinet, it behaved in the same way as its opponents. The mystique of the throne worked.

Indeed, it has been necessary that regional economic imbalances reached alarming levels to rekindle the flame of contestation, leading the financial elites to retake the trenches of liberalism (always it!) and the march of the provincial fights, asleep during the second reign. Interestingly, the path that led to the end of the monarchy was very similar to that which allowed the early arrival of Pedro II to the throne. And always, the liberal flag followed being agitated, bending in favor of the winds of every moment.

\section{CONCLUSION}

The data analyzed in this study allow us to conclude that there has never been a pure liberal thought, mirror of the ideals present in the European revolutions, able to co-opt expressive portions of national political leaderships. The fear of social disorder, the attachment to slavery, the economic dependence on the State, the centralizing tradition and the authoritarian inheritance are some elements that help to understand the fate of the country and the rejection of any ideology that is minimally open to an effective popular participation.

Throughout the imperial era, the country depended almost exclusively on exporting primary products (first, sugar cane, then coffee), which created between government and producers a relationship of mutual dependence. The former needed external sales to obtain resources, the latter were graced by the government with minimal prices, financing, guarantees for export contracts, and the maintenance of the slave labor. The rural lords were decisive to define the directions of the country at various times, constituting the point of support that allowed successive oscillations in the axis of power.

The different groups that polarized the political spectrum in the analyzed period approached and drifted away according to the tides, as spokesmen of wind's ideologies, weakly sustained by speeches that, at various times, were nothing more than a mockery of liberalism. The insistence on the use of this

poblaciones indigenas, tan distintas y tan complejas como las de las Américas española y portuguesa?" 
term, in fact, seems more a strategy to cover up a deeply conservative and elitist thought.

Since the independence, following the Portuguese heritage, the State has been the central point of the social organization, the mainstay of rural producers, merchants and other hegemonic social segments. A State that forms from itself and primarily attends its own interests, keeping the people on the sidelines. Rulers that use the defense of the order and the social stability to subjugate society and to set apart its action of any kind of popular scrutiny. In a scenario like this, it is understood the naturalness with which even the most acidic critics of monarchical authoritarianism cling to the statism and end up yielding to the decision centralism and the weight of the royal mantle.

A country that was born largely thanks to the success of a liberal revolution - the Porto Revolution, in the midst of an opposition against the remnants of the absolutism that the Vienna Congress attempted to preserve, ended up a slave of its retrograde elite, unable to break with the authoritarian Portuguese inheritance, hostage of a discourse that scarcely represented the reality. A liberal project that, in the end, allowed to confer an appearance of legitimacy to a Brazil that developed itself aparted of the Law and averse to the freedom.

\section{REFERENCES}

BARRADAS, Abril Uscanga. Problemas de la democracia liberal: un breve análisis. Revista Brasileira de Direito. Passo Fundo, vol. 14, n. 1, Jan./Abr. 2018. Available in

$$
\text { < https://seer.imed.edu.br/index.php/revistadedireito/article/view/2093 > }
$$

BONAVIDES, Paulo; ANDRADE, Paes de. História Constitucional do Brasil. 3. ed. São Paulo: Paz e Terra, 1991.

CALDEIRA, Jorge. Introdução. in CALDEIRA, Jorge (org). Diogo Antonio Feijó. Coleção Formadores do Brasil. São Paulo: Editora 34, 1999.

CASTRO, Araújo. A Constituição de 1937. edição fac-similar. Brasília: Senado Federal, 2003.

CERQUEIRA, Marcelo. Notas à Constituição. Como foram convocadas as constituintes. Brasília: Imprensa Nacional, 1985.

COMPARATO, Fábio Konder. Prefácio. in COMPARATO, Fábio Konder (org.). A República Inacabada. São Paulo: Globo, 2007.

DOLHNIKOFF, Miriam. Introdução. in DOLHNIKOFF, Miriam (org.). José Bonifácio de Andrada e Silva. Projetos para o Brasil. São Paulo: Companhia das Letras, 2000.

FAORO, Raymundo. Os Donos do Poder. Formação do patronato político brasileiro. 3. ed. São Paulo: Globo, 2001.

FAORO, Raymundo. Existe um Pensamento Político Brasileiro? in COMPARATO, Fábio Konder (org.). A República Inacabada. São Paulo: Globo, 2007.

FIORAVANTI, Maurizio. Constitucionalismo. Experiencias históricas y tendências actuales. Madrid: Trotta, 2014. 
FURTADO, Celso. Formação Econômica do Brasil. 34. ed. São Paulo: Companhia das Letras, 2007.

GOMES, Jônatas Roque Mendes. A revolução liberal do Porto e as concepções de pacto social no parlamento brasileiro (1826-1831). Passagens. Revista Internacional de História e Cultura Jurídica. Vol. 10, n. 1. Rio de Janeiro, jan./abr. 2018. Available in

< http://www.revistapassagens.uff.br/index.php/Passagens/article/view/155 >

LACCHÉ, Luigi. Las Cartas Otorgadas. La teoría de l'octroi y las experiencias constitucionales en la Europa post-revolucionaria. in Fundamentos. Cuadernos Monográficos de Teoría del Estado, Derecho Público e Historia Constitucional. Oviedo: Junta General del Principado de Asturias, n. 6. 2010. Available in < https://dialnet.unirioja.es/ejemplar/286118 >

LEAL, Aurelino. História Constitucional do Brasil. edição fac-similar. Brasília: Senado Federal, 2002.

LESSA, Antônio Carlos. História das Relações Internacionais. A Pax Britannica e o mundo do século XIX. Vol. I. 4. ed. Petrópolis: Vozes, 2011.

LINCH, Christian Edward Cyril. 'Monarquía sin despotismo y libertad sin anarquía'. Historia del concepto de liberalismo en Brasil (1750-1850). in SEBASTIÁN, Javier Fernández (org.). La Aurora de la Libertad. Los primeros liberalismos en el mundo ibero-americano. Madrid: Marcial Pons, 2012.

LINCH, Christian Edward Cyril. Conservadorismo Caleidoscópico: Edmund Burke e o pensamento político do Brasil oitocentista. Revista Lua Nova. São Paulo, n. 100, 2017. Available in < http://www.scielo.br/scielo.php?pid=S010264452017000100313\&script $=$ sci_abstract\&tlng $=$ pt $>$

MAGNOLI, Demétrio. Congresso de Viena (1814-1815). in MAGNOLI, Demétrio (org.) História da Paz. Os tratados que desenharam o planeta. São Paulo: Contexto, 2012.

MONDAINI, Marco. Guerras Napoleônicas. in MAGNOLI, Demétrio (org). História das Guerras. 3. ed. São Paulo: Contexto, 2006.

NOGUEIRA, Octaciano. Constituições Brasileiras: 1824. Vol. I. Brasília: Senado Federal, 2001.

REIS, Fábio Wanderley. Estado liberal, projeto nacional, questão social. in Mercado e Utopia [online]. Rio de Janeiro: Centro Edelstein de Pesquisas Sociais, 2009. Available in SciELO Books < http://books.scielo.org/id/v7ywf/pdf/reis9788599662793-15.pdf >

SALDANHA, Nelson Nogueira. História das Ideias Politicas no Brasil. Brasília: Senado Federal, 2001.

SEBASTIÁN, Javier Fernández. Introducción. En busca de los primeros liberalismos iberoamericanos. in SEBASTIÁN, Javier Fernández (org.) La Aurora de la Libertad. Los primeros liberalismos en el mundo ibero-americano. Madrid: Marcial Pons, 2012.

SOUSA, Octávio Tarquínio de. Três Golpes de Estado. História dos Fundadores do Império do Brasil. São Paulo: Editora USP, 1988. 
SOUSA, Octávio Tarquínio de. Fatos e Personagens em Torno de um Regime. História dos Fundadores do Império do Brasil. São Paulo: Editora USP, 1988.

WAQUIM, Bruna Barbieri; COELHO, Inocêncio Mártires; GODOY, Arnaldo Sampaio de Moraes. A história constitucional da infância no Brasil à luz do caso do menino Bernardino. Revista Brasileira de Direito. Passo Fundo, vol. 14, n. 1, Jan./Abr. 2018. Available in

< https://seer.imed.edu.br/index.php/revistadedireito/article/view/1680 >

Fecha de envío / Submission date: 16/04/2019

Fecha de aceptación / Acceptance date: 22/07/2019 